\title{
THE OPTIMIZATION OF MULTIPURPOSE BUILDING DEVELOPMENT ON PROJECT SCHEDULING USING PRECEDENCE DIAGRAM METHOD (PDM)
}

\author{
Sutrisno, Ahmadi Okol S Suharyo \\ Indonesian Naval Technology College, STTAL. \\ Bumimoro-Morokrembangan, Surabaya 60187, Indonesia
}

\begin{abstract}
The current development of construction projects lead to construction projects being more complex and complicated. The success or failure of a project can be due to inadequate planning and less effective controls, resulting in inefficient projects. This will result in delays, lower quality, and increased implementation costs. All of those problems are expected to be overcome with Presedence diagram method by reducing the impact of delay and swelling of project cost by crashing with applied overtime. Acceleration of duration on the critical path jobs was performed. The results with PDM indicated that the optimal duration of project was 100 days with efficiency time for 20 days or equal to $16,67 \%$ and the total cost of $R p 13,060,754,232.00$ with cost efficiency equal to $R p$ $528,158,094.00$ or $3,88 \%$.
\end{abstract}

Keywords: Crashing, Controlling, Planning, PDM.

\section{INTRODUCTION.}

The current development of construction project lead to makes construction projects more complex and complicated due to the large and complex projects that require resources from the beginning to the end of the project (Ikhtisholiyah, 2017). Project is basically a process of making a unique product, either in the form of a new product or running a new business type that will be completed within a certain time (Muhammad Kholil, 2018). There are three important aspects that must be considered in the implementation of a project that is cost, time, and quality. A project is considered to be successful if the time and work cost are in accordance with the planning and quality. In addition, the quantity of work meet the requirements that have been determined (M. Hayuningtyas, 2018).

The literature used in this paper were obtained to support the research. These literature includes paper titled A fuzzy pert approach to evaluate plant construction project scheduling risk under uncertain resources capacity (R.Lin, 2009). Earned Value Management Systems: Challenges and Future Direction (Wilson, 2013). CPM, PERT and Project Management With Fuzzy Logic Technique and Implementation On A Business (Mazlum, 2015). Integration of Building Information Modeling and Critical Path Method Schedules to Simulate the Impact of Temperature and Humidity at the Project Level (Shan, 2014). Comparative Study of Management Operation System Techniques (MOST) and CPM in Construction Scheduling (Shailla, 2014). Extension of Time Determination in Construction Projects in Nigeria: The Critical Path Method (Andawei, 2014). Critical path analysis for the management of fractured neck of femur (Balla, 1995). The Critical Path Method In Estimating Project Duration (Nafkha, 2016). Critical Path Analysis for New Product Planning (Wong, 1964). Measuring the Actual Energy Cost Performance of Green Buildings: A Test of the 
Earned Value Management Approach (Dwaikat, 2016). Cost Control and Performance Review of Software Projects by Using the Earned Value Management (Alecu, 2014). Critical Path Method in Designing Feasible Solutions (Agarwal, 2013). Traditional Critical Path Method versus Critical Chain Project Management: A Comparative View (M, 2015). Project Planning And Control With Pert And Cpm (K.K.Khandelwal, 2002). Project Planning And Scheduling Using PERT And CPM Techniques With Linear Programming: Case Study (Agyei, 2015). Fast Missile Boat Project Planning using CPM and What If Analysis Method (Silvianita, 2018). CPM Schedule Summarizing Function of the Beeline Diagram Method (Kim, 2012). Earned value method as a tool for project control (Czarnigowska, 2008). The Factors Affecting The Methods of Construction Projects Scheduling: An State of The Art and Overview (Fatemeh Nouban, 2017). Contruction Project Scheduling with Time, Cost and Material Restrictions Using Fuzzy Mathematical Models and Critical Path Method (Daniel CastroLacouture, 2009). Planning and Monitoring of industrial punch development processes (Y. Arslan, 2017).

PDM basically focuses on the equilibrium of cost and project completion time. PDM emphasizes the relationship between the use of labor or resources to shorten the execution time of a project and incremental costs as a result of additional resources.

This Paper is organized as follows. Section 2 review about the basic ship theory. Section 3 gives result and section 4 discussion of research. Finally, in section 5 present conclusion this paper.

\section{MATERIALS AND METHODS}

\section{Technical Concept}

In determining the exact duration factors:

1. Volume of work

2. The condition in project fields
3. Weather conditions

4. Resources conditions (labor, materials, equipment)

5. Experiences on previous project (similar project)

\section{Project Time Management}

There are three stages to be performed in project management:

\section{Planning Process}

Planning process includes the setting of goals, defining projects and forming team organizations. Regarding the capability in working on several projects at once (mostly in large companies), an effective way to assign labors and physical resources is through the project organization. The project organization is led by a project manager who coordinates project activities with other departments and reports to top management.

\section{Scheduling}

Scheduling is the link between labor, money, and materials used in a project. Project scheduling involves specifying the duration of project activities to be completed, raw materials, labor and time required for each activity. The popular approach used is the Gantt Chart or the Bar Chart Method. Other project scheduling methods are PERT (Project Evaluation and Review Technique) and CPM (Critical Path Method).

\section{Controlling}

Project controls include control over resources, cost, quality and budget. Project control is also used to revise the project plan and allow to change/shift resources to a needed places (rearranging) so that the time and cost can be appropriate. Project control involves strict supervision of resources, cost, quality and budget. Control also means the use of feedback loops to revise the project 
plan and resource arrangements where needed.

\section{Network Component}

There are two approaches to describe the project network: activity on node - AON and activity on arrow (AOA). At the AON convention, the point indicates the activity, whereas at the AOA, the arrow indicates the activity.

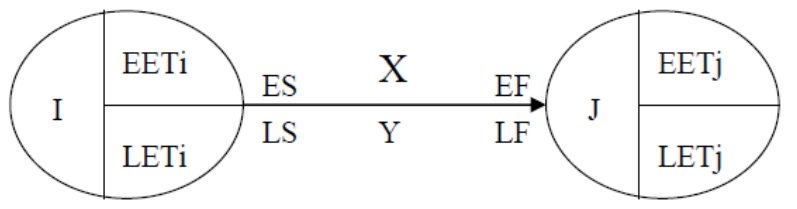

Fig. 1 Activity On Arrow

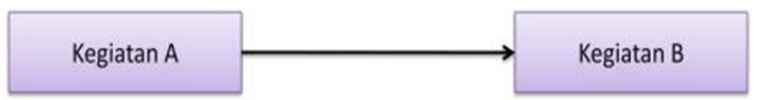

Fig. 2 Activity On Node

\section{Precedence Diagram Method (PDM)}

Precedence Diagram Method is a networking method that is included in the classification of AON (Activity On Node). In this method, the activity is written in a node that is generally rectangular, while the arrows as a pointer relationship between the activities concerned. Thus the dummy which is an important sign to indicate the dependence relationship, is not required in PDM.

In the precedence diagram method, the existence of four relations of activity/logic can be described. Each node has two ends namely the beginning/starting tip $=(S)$ and end/finish tip $=(F)($ Tan, 1998):

1. Activity relation of Start-to-start (SS): When A starts, B can be started.

2. Activity Relation of Start-to-finish (SF): When A starts, B can be finished.

3. Activity Relation Finish-to-Start (FS): When A finish, B can be started.
4. Activity Relation Finish-to-finish (FF): When $A$ finish, $B$ can be finished.

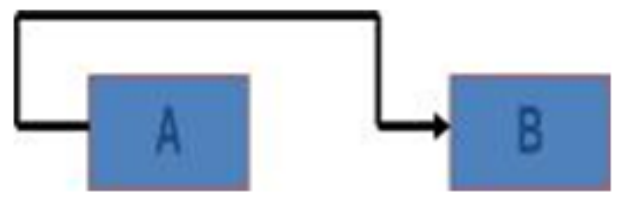

Fig. 3 Activity Relation of Start-to-Start (SS)

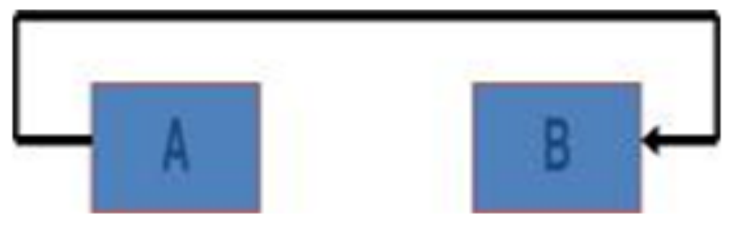

Fig. 4 Activity Relation of Start-to-Finish (SF)

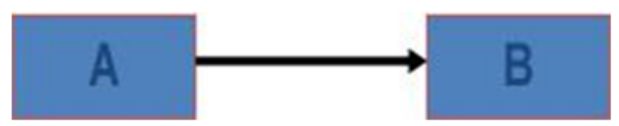

Fig. 5 Activity Relation of Finish-to-Start (FS)

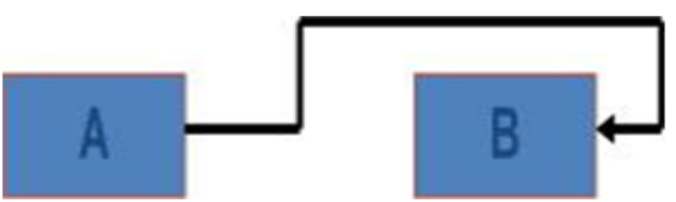

Fig. 6 Activity Relation of Finish-to-Finish (FF)

\section{Cost Analysis}

The definition of Cost is the economic resources sacrifice as measured by units of money, to obtain goods or services that are expected to provide current and future benefits. The sacrifice of these economic resources could be historical costs and future costs. While in the narrow sense, cost can be interpreted as a sacrifice of economic resources to acquire assets or to earn income indirectly as called by the cost of goods.

In the implementation of a project, inputs are required. These inputs will be processed by a certain level of difficulty and time so that the project objectives are achieved. In other words, one of the requirements for the ultimate goal of the project can be achieved, is the presence of 
necessary inputs which consist of resources, labor, equipment, materials and these inputs must be ready for use at the time of execution, and meet the quality standards. The objective of this cost analysis is to study the amount of costs required during the project.

\section{Method of Research.}

The following is the structure to be designed in this paper:

1. This multipurpose building was designed by reducing the risk of delay by optimizing the time and cost in the project development of implementation.

2. Analysis and method of this paper is literature study, field study, and model simulation using PDM.

\section{RESULT.}

In this part, the authors would like to discuss about critical path with PDM, the time required by increasing the number of workers and the addition of overtime and optimizing the cost of development projects in order to achieve the expected development implementation.

\section{Project Time Planning}

The factors that normally affect the project's execution time in activities to complete this multipurpose building development project are needed to take into account. The stages of making the development project planning are described as follows:

1. Conduct a survey to the project site.

2. Identify the location of the project.

3. Create alternative physical image of project building

4. Make a work plan in the form of a wages list, materials list, job list.

5. Create a budget plan in the form of a wages list, materials list, job list.

\section{Project Budget Planning}

To draw up a project budget plan, these following steps are usually performed:

1. Collecting data on the type, price and market capacity of providing materials continuously.

2. Collecting data on wages of labors applied in the city or district.

3. Analyze the materials and wages of workers for the project to be performed

4. Calculating the unit price of labors by utilizing analysis results of unit labors and work quantity list

5. Arranging the recapitulation of budget plan of project cost

\section{DISCUSSION.}

Table 1. Labors and Daily Wages in Architecture Jobs

\begin{tabular}{|c|l|c|}
\hline No & \multicolumn{1}{|c|}{ Description } & Unit Wage \\
\hline 1 & Carpenter & $73,000.00$ \\
\hline 2 & Bricklayer & $73,000.00$ \\
\hline 3 & Blacksmith & $73,000.00$ \\
\hline 4 & Painter & $73,000.00$ \\
\hline 5 & Dugger & $73,000.00$ \\
\hline 6 & Plumber & $73,000.00$ \\
\hline 7 & Electrician & $73,000.00$ \\
\hline 8 & Welder & $73,000.00$ \\
\hline 9 & Workers & $73,000.00$ \\
\hline 10 & Head of Handyman & $110,000.00$ \\
\hline 11 & Heavy equipment operator & $140,000.00$ \\
\hline 12 & Foreman & \\
\hline & & \\
\hline
\end{tabular}

Table 2. The Recapitulation of Project Budget Plan

\begin{tabular}{|c|c|c|}
\hline No & Job Description & Cost \\
\hline 1 & $\begin{array}{l}\text { Architecture Jobs of Multipurpose } \\
\text { Building }\end{array}$ & Rp $4,283,735,071.00$ \\
\hline 2 & $\begin{array}{l}\text { Structural Jobs of Multipurpose } \\
\text { Building }\end{array}$ & $\operatorname{Rp} 3,003,540,054.00$ \\
\hline 3 & $\begin{array}{l}\text { Mechanical-Electrical Works of } \\
\text { Multipurpose Building }\end{array}$ & $\operatorname{Rp} 3,580,950,088.00$ \\
\hline
\end{tabular}




\begin{tabular}{|r|l|}
\hline TOTAL AMOUNT & Rp 10,868,225,213.00 \\
\hline PPN 10\% & Rp 1,086,822,521.30 \\
\hline SUB TOTAL & Rp 11,955,047,734.30 \\
\hline ROUNDED TOTAL & Rp 11,955,050,000.00 \\
\hline
\end{tabular}

Table 3. List of Event Sequences and Estimated Time

\begin{tabular}{|c|l|c|c|c|}
\hline No & Job Description & $\begin{array}{c}\text { Activity } \\
\text { Code }\end{array}$ & $\begin{array}{c}\text { Previous } \\
\text { Activity }\end{array}$ & $\begin{array}{c}\text { Time } \\
\text { (Days) }\end{array}$ \\
\hline 1 & $\begin{array}{l}\text { Door and Window } \\
\text { Job }\end{array}$ & A & & 13 \\
\hline 2 & Wall-build Job & B & A & 24 \\
\hline 3 & $\begin{array}{l}\text { Ceiling Installation } \\
\text { Job }\end{array}$ & C & A & 18 \\
\hline 4 & $\begin{array}{l}\text { Floor and Wall } \\
\text { Coating Job }\end{array}$ & D & A & 30 \\
\hline 5 & Sanitary Job & E & A & 12 \\
\hline 6 & $\begin{array}{l}\text { Wall and Ceiling } \\
\text { Painting Job }\end{array}$ & F & D & 12 \\
\hline 7 & Electrical Job & G & D & 36 \\
\hline 8 & Mechanical Job & H & G & 25 \\
\hline 9 & Electronics Workers & I & G & 20 \\
\hline 10 & Roof Job & J & D & 8 \\
\hline 11 & Ralling Job & K & C & 12 \\
\hline 12 & Garden Job & L & E & 12 \\
\hline 13 & Channel Job & M & E & 10 \\
\hline
\end{tabular}

Table 4. List of Job Direct Cost

\begin{tabular}{|c|c|c|}
\hline No & Job Description & Cost \\
\hline 1 & Door and Window Job & Rp 260,351,900.55 \\
\hline 2 & Wall-build Job & Rp 850,781,870.45 \\
\hline 3 & Ceiling Installation Job & Rp 610,399,760.34 \\
\hline 4 & Floor and Wall Coating Job & Rp 3,570,991,706.37 \\
\hline 5 & Sanitary Job & Rp 299,351,888.12 \\
\hline 6 & Wall and Ceiling Painting Job & Rp 220,764,340.99 \\
\hline 7 & Electrical Job & Rp 1,470,351,970.65 \\
\hline 8 & Mechanical Job & Rp 1,400,987,800.50 \\
\hline 9 & Electronics Workers & Rp 860,320,890.90 \\
\hline 10 & Roof Job & Rp 560,357,345.33 \\
\hline 11 & Ralling Job & Rp 80,356,989.58 \\
\hline 12 & Garden Job & Rp 120,390,911.22 \\
\hline 13 & Channel Job & Rp 85,356,290.10 \\
\hline
\end{tabular}

Table 5. List of Activity Cost Slope

\begin{tabular}{|c|c|c|c|c|}
\hline $\begin{array}{c}\text { Job } \\
\text { Activities }\end{array}$ & $\begin{array}{l}\text { Normal Cost } \\
\text { (Rp) }\end{array}$ & $\begin{array}{l}\text { Time } \\
\text { (Days) }\end{array}$ & $\begin{array}{l}\text { Accelerated } \\
\text { Cost (Rp) }\end{array}$ & $\begin{array}{c}\text { Slope of } \\
\text { Cost/Day } \\
\text { (Rp) }\end{array}$ \\
\hline A & $\begin{array}{c}\mathrm{Rp} \\
260,351,900.55\end{array}$ & 13 & $\begin{array}{c}\mathrm{Rp} \\
260,351,900.55\end{array}$ & \\
\hline B & $\begin{array}{c}\mathrm{Rp} \\
850,781,870.45\end{array}$ & 24 & $\begin{array}{c}\mathrm{Rp} \\
850,781,870.45\end{array}$ & $\begin{array}{c}\mathrm{Rp} \\
128,300.00\end{array}$ \\
\hline $\mathrm{C}$ & $\begin{array}{c}\mathrm{Rp} \\
610,399,760.34\end{array}$ & 18 & $\begin{array}{c}\mathrm{Rp} \\
610,399,760.34\end{array}$ & \\
\hline $\mathrm{D}$ & $\begin{array}{c}\mathrm{Rp} \\
3,570,991,706.37\end{array}$ & 30 & $\begin{array}{c}\mathrm{Rp} \\
3,570,991,706.37\end{array}$ & \\
\hline$E$ & $\begin{array}{c}\mathrm{Rp} \\
299,351,888.12\end{array}$ & 12 & $\begin{array}{c}\mathrm{Rp} \\
299,351,888.12\end{array}$ & \\
\hline $\mathrm{F}$ & $\begin{array}{c}\mathrm{Rp} \\
220,764,340.99\end{array}$ & 12 & $\begin{array}{c}\mathrm{Rp} \\
220,764,340.99\end{array}$ & \\
\hline $\mathrm{G}$ & $\begin{array}{c}\mathrm{Rp} \\
1,470,351,970.65\end{array}$ & 36 & $\begin{array}{c}\mathrm{Rp} \\
1,470,351,970.65\end{array}$ & \\
\hline $\mathrm{H}$ & $\begin{array}{c}\mathrm{Rp} \\
1,400,987,800.50\end{array}$ & 25 & $\begin{array}{c}\mathrm{Rp} \\
1,400,987,800.50\end{array}$ & \\
\hline 1 & $\begin{array}{c}\mathrm{Rp} \\
860,320,890.90\end{array}$ & 20 & $\begin{array}{c}\mathrm{Rp} \\
860,320,890.90\end{array}$ & \\
\hline$J$ & $\begin{array}{c}\mathrm{Rp} \\
560,357,345.33\end{array}$ & 8 & $\begin{array}{c}\mathrm{Rp} \\
560,357,345.33\end{array}$ & $\begin{array}{c}\mathrm{Rp} \\
220,000.00\end{array}$ \\
\hline $\mathrm{K}$ & Rp 80,356,989.58 & 12 & $\begin{array}{c}\mathrm{Rp} \\
80,356,989.58\end{array}$ & $\begin{array}{c}\mathrm{Rp} \\
120,400.00\end{array}$ \\
\hline L & $\begin{array}{c}\mathrm{Rp} \\
120,390,911.22\end{array}$ & 12 & $\begin{array}{c}\mathrm{Rp} \\
120,390,911.22\end{array}$ & \\
\hline M & Rp $85,356,290.10$ & 10 & $\begin{array}{c}\mathrm{Rp} \\
85,356,290.10\end{array}$ & \\
\hline
\end{tabular}

Table 6. Total of Project Cost after Accelerated

\begin{tabular}{|c|c|c|c|}
\hline No & Activity & Time & Total Cost \\
\hline 1 & Normal Activity & 120 & Rp 13,588,912,336.00 \\
\hline 2 & $\begin{array}{l}\text { K activity being accelerated } \\
\text { by } 4 \text { days }\end{array}$ & 116 & Rp $13,467,810,382.00$ \\
\hline 3 & $\begin{array}{l}\text { B activity being accelerated } \\
\text { by } 6 \text { days }\end{array}$ & 110 & Rp 13,254,230,654.00 \\
\hline 4 & $\begin{array}{l}\mathrm{J} \text { activity being accelerated } \\
\text { by } 10 \text { days }\end{array}$ & 100 & Rp $13,060,754,232.00$ \\
\hline
\end{tabular}

\section{CONCLUSION.}

The efficiency of time and cost of the project by using PDM network planning method was calculated as follows:

Efficiency Time: $120-100=20$ Days or $20 / 120 \times 100 \%=16.67 \%$

Efficiency of Project Cost: Rp

$13,588,912,336.00-\operatorname{Rp~13,060,754,232.00=}$ 


\section{ACKNOWLEDGEMENTS.}

This research has been Supported by Indonesia Naval Technology College (STTAL).

\section{BIBLIOGRAPHY.}

Agarwal, R., 2013. Critical Path Method in Designing Feasible Solutions. International Journal of Scientific Research and Reviews, pp. 190-202.

Agyei, W., 2015. Project Planning And Scheduling Using PERT And CPM Techniques With Linear Programming: Case Study. INTERNATIONAL JOURNAL OF SCIENTIFIC \& TECHNOLOGY RESEARCH, pp. 222-227.

Alecu, F., 2014. Cost Control and Performance Review of Software Projects by Using the Earned Value Management. Oeconomics of Knowledge, pp. 2-6.

Andawei, M.-E. M., 2014. Extension of Time Determination in Construction Projects in Nigeria: The Critical Path Method. The International Journal Of Engineering And Science (IJES), pp. 48-51.

Balla, G. T., 1995. Critical path analysis for the management of fractured neck of femur. AUSTRALIAN JOURNAL OF PUBLIC HEALTH, pp. 155-159.

Czarnigowska, A., 2008. Earned value method as a tool for project control. Budownictwo i Architektura 3, pp. 15-32.

Daniel Castro-Lacouture, A. G. A. S. J. G.-J. a. J. K. Y., 2009. Contruction Project Scheduling with Time, Cost and Material Restrictions Using Fuzzy Mathematical Models and Critical Path Method. JOURNAL OF CONSTRUCTION ENGINEERING AND MANAGEMENT, pp. 1096-1104.

Dwaikat, L. N., 2016. Measuring the Actual Energy Cost Performance of Green Buildings: A Test of the Earned Value Management Approach. Energies journal, pp. 1-20.

Fatemeh Nouban, N. G., 2017. The Factors Affecting The Methods of Construction Projects Scheduling: An State of The Art and Overview. Asian Journal of Natural \& Applied Sciences, 6(4), pp. 114-122.
Ikhtisholiyah, 2017. analysis of the application of time and cost management on the construction project of electric engineering building of polytechnic industry of madura (poltera). Zeta-Math Journal, pp. 14-21.

K.K.Khandelwal, D. B., 2002. PROJECT PLANNING AND CONTROL WITH PERT AND CPM. New Delhi: LAXMI PUBLICATIONS (P) LTD..

Kim, S.-G., 2012. CPM Schedule Summarizing Function of the Beeline Diagram Method. Journal of Asian Architecture and Building Engineering, pp. 367-374.

M. Hayuningtyas, T. D., 2018. System analysis for technology transfer readiness assessment of horticultural postharvest. Bogor, IOP Publishing, pp. 1-7.

Mazlum, M., 2015. CPM, PERT and Project Management With Fuzzy Logic Technique and Implementation On A Business. Istanbul, Elsevier Ltd, pp. 348-357.

M, S., 2015. Traditional Critical Path Method versus Critical Chain Project Management: A Comparative View. International Journal of Economics \& Management Sciences , pp. 1-6.

Muhammad Kholil, B. N. A. M. H., 2018. Scheduling of House Development Projects with CPM and PERT Method for Time Efficiency (Case Study: House Type 36). jakarta, IOP Publishing, pp. 1-8.

Nafkha, R., 2016. THE CRITICAL PATH METHOD IN ESTIMATING PROJECT DURATION. Information Systems in Management, pp. 78-87.

R.Lin, H. J., 2009. A fuzzy pert approach to evaluate plant construction project scheduling risk under uncertain resources capacity. Journal of Industrial Engineering and Management, pp. 3147.

Shailla, 2014. Comparative Study of Management Operation System Techniques (MOST) and CPM in Construction Scheduling. International Journal of Engineering Trends and Technology (IJETT), pp. 371-379.

Shan, Y., 2014. Integration of Building Information Modeling and Critical Path Method Schedules to 
Simulate the Impact of Temperature and Humidity at the Project Level. buildings jounal, pp. 295-319.

Silvianita, R. F. D. M. R. S. a. D. M. C., 2018. Fast Missile Boat Project Planning using CPM and What If Analysis Method. jakarta, IOP Publishing, pp. 1-6.

Wilson, B., 2013. Earned Value Management Systems: Challenges and Future Direction. Journal of Integrated Enterprise Systems, pp. 9-17.
Wong, Y., 1964. Critical Path Analysis for New Product Planning. Journal of Marketing, pp. 53-59.

Y. Arslan, H. B. M. E., 2017. Planning and Monitoring of industrial punch development processes. Journal of Engineering Research and Applied Science, pp. 615-622. 